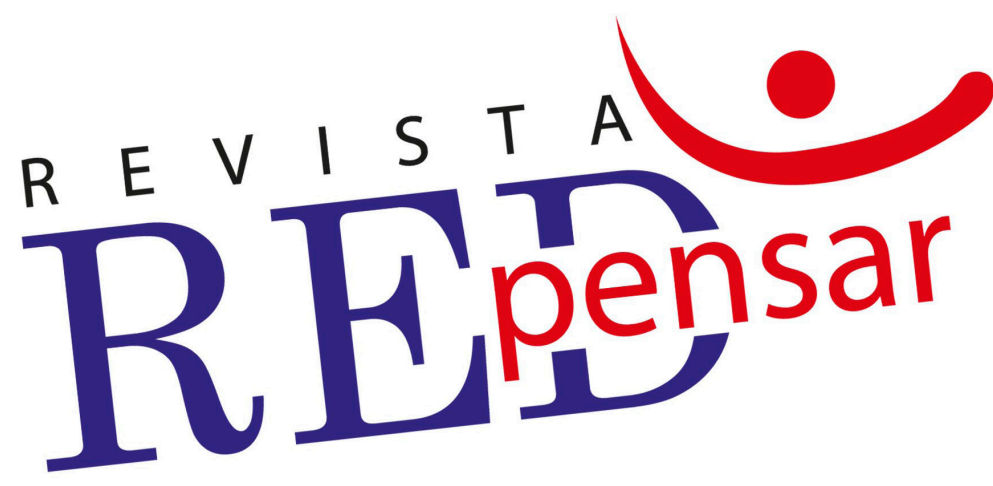

\title{
A la escuela que se quiere llegar
}

To the school that is wanted to arrive

\section{Miranda Rojas Rubiria}

Revista REDpensar, volumen 5, número 2, Ago-Dic 2016

ISSNe: 2215-5384

Revelando otras prácticas 3

Recibido: 21 de junio del 2017 Aceptado: 12 de octubre del 2017

Publicado: 07 de abril de 2018

DOI: 10.31906/redpensar.v5i2.124

\section{(ㄷ)(1) $\$(0)$}

Universidad De La Salle Costa Rica

Departamento de Investigaciones

redpensar@ulasalle.ac.cr | www.redpensar.ulasalle.ac.cr 


\title{
A la escuela que se quiere llegar To the school that is wanted to arrive
}

\begin{abstract}
Sarita no quiere levantarse, son las cinco de mañana y es hora de arreglarse para ir a estudiar. Todas las noches se queja de algún dolor que la hace trasnochar, y a la mañana siguiente, se disgusta con su mamá, porque la obliga ir a estudiar.
\end{abstract}

Se ducha a regañadientes y el uniforme de cuadros se debe de colocar, algunas veces desayuna, pero no le agrada nada de lo que su mamá madruga a preparar, espera la ruta y cuando pita, hay que recordarle que tiene que bajar, se despide con desagrado, con ganas de decir “¡Ya no más!!!”.

Al llegar de la escuela, revisa el almanaque que cuelga en algún lugar,

Pues todos los días cuenta los días que no tiene que ir a estudiar, anhela con ansias el hermoso sábado y domingo que no tiene que ir por allá.

En las tardes, pasa las horas en el balcón de su casa, mirando las verdes montañas que tiene en frente de su hogar, preguntándose una y otra vez: ¿Por qué no vivo en ese lugar?.

Se imagina que es Tarzan y le pide a su madre que la deje en la montaña, que no se preocupe, que ella va estar bien allá, pues no hay escuelas que la obliguen estudiar.

Su mamá, le explica que los habitantes de las montañas también tienen que estudiar, que les toca más duro porque tienen que caminar largas horas entre el matorral.

Pasa la tarde y ella no quiere ni mirar las tareas que le dejan para repasar.

Se sienta e intenta leer lo que tiene que hacer, pero rápido desiste de su responsabilidad

y empieza la batalla campal, por cumplir con algo que no ama ni le interesa abordar.

Sin embargo, se esfuerza y con mucha paciencia su madre, le ayuda a culminar las actividades que al otro día debe entregar.

Así pasan los días, las semanas y los años y Sarita no quiere más una escuela tradicional.

Su mamá que es docente, empieza a comprender lo que ella requiere de verdad.

Y por andares de la vida en su devenir escucho algo de una educación alternativa que le podría interesar.

Fue así que se dio la tarea de averiguar si existía en su ciudad una educación diferente que la hiciera emocionar.

Entre ires y venires se encontró con una iniciativa que la supo enamorar,

No era educación formal y no tenía el aval estatal, pero sabía que esto si le iba a interesar a su pequeña Sarita, que quería experimentar algo diferente de lo que ya había vivido en años atrás.

1. Magister en Educación. Especialista en Pedagogía, profesional en Ciencias Sociales de la Universidad de Tolima, Colombia. Correo electrónico: mirandarubiria@gmail.com 
Es así que Sarita ahora se levanta feliz porque la van a llevar,

al mejor lugar donde puede ir a jugar, reír, aprender, disfrutar y amar.

Es feliz en su casa acogedora porque se puede relacionar con niños y niñas de diferentes edades que también les gusta jugar, cantar, bailar, crear, diseñar y soñar.

Ha dejado de un lado lapiceros, transportador, reglas y cuadernos de princesas, por una botas de hule, delantal, pinturas, telas y lanas para aprender y jugar.

Entre arcilla, la huerta, la quebrada, la merienda y mucho más, la familia ha notado el cambio que la motiva a experimentar,

y al llegar a su casa, su rostro evidencia que su espíritu se ha alimentado de todo lo que ella soñó y mucho más.

Esta es la historia de mi hija, que ahora tiene diez años y no quería ir a estudiar, pero ahora es feliz todos los días cuando sale y llega de ese hermoso lugar, donde ella se auto reivindicó primero como persona y es feliz, que es lo principal. 